\title{
Um confronto literário: abolição e cidadania negra na ficção baiana da Primeira República
}

Marcelo Souza Oliveira ${ }^{1}$

\begin{abstract}
Resumo
O texto analisa como as questões que envolviam a abolição poderiam implicar em modelos de cidadania para o negro na Bahia da Primeira República. Para isto, avalio a ficção produzida por Anna Ribeiro (1843-1930) e Xavier Marques (1860-1942). Ela ex-senhora de engenho e de escravos. Ele, jornalista e abolicionista. $\mathrm{Na}$ literatura dela, a abolição teria sido fruto da "imprevidência da Princesa Isabel e seus Ministros". Na prosa dele, a abolição teria sido um processo provocado por abolicionistas e negros. Ela constrói enredos e personagens que expressam o paternalismo peculiar as elites baianas. Para ele, os tipos sociais indicam que negros e mestiços teriam sido sujeitos de sua própria liberdade - e posterior cidadania. São representações e discursos distintos que indicam o lugar social daqueles que os produziu. Um confronto literário que, na ficção, discutia modelos baseados nos conceitos de raça e cidadania veiculados no decorrer do Brasil da Primeira República.
\end{abstract}

Palavras-Chave: Literatura; pós-abolição; cidadania.

\section{Abstract}

The paper looks at how the issues involving the abolition of models could lead to citizenship for the Negro in Bahia in the First Republic. For this, I evaluate the fiction produced by Anna Ribeiro (1843-1930) and Xavier Marques (1860-1942). She ex-mistress of a plantation and slaves. He, journalist and abolitionist. In her literature, the abolition would have been the result of "miscalculation of Princess Isabel and her ministers." In his prose, the abolition would have been a process triggered by abolitionists and blacks. She builds her plots and characters that express the peculiar paternalism Bahian elites. For him, social types indicate that blacks and hybrids had been subjects of their own freedom - and later citizenship. They representations and discourses that indicate the distinct social place of those who produced them. A confrontation that literary, fiction, discussing models based on concepts of race and citizenship served during the First Republic of Brazil.

Keywords: Literature; post-abolition; citizenship.

Amparo dos Cativos, Recôncavo Baiano, 1871. Uma tradicional cavalhada reúne a maior parte da população da cidade. Muitos senhores de engenho trazem sua família, agregados, mucamas e alguns escravos de confiança para presenciarem ao evento que marcaria o apogeu do sistema senhorial naquele lugar. Em meio a comemorações e muita fartura o Visconde de Athaípe, chefe político da cidade, assiste de camarote às exibições dos cavaleiros. De repente, um homem mascarado apresenta-se, vence a competição e dedica a sua vitória à filha do Visconde, a bela Augusta Leite. Ao tirar a máscara o cavaleiro provoca uma estupefação geral ao revelar sua verdadeira identidade: tratava-se, na verdade, de um mestiço liberto chamado Nazário.

\footnotetext{
1 Professor do Instituto Federal de Educação, Ciências e Tecnologia Baiano - Campus Catu. Doutorando em História
} Social pela Universidade Federal da Bahia. 
O episódio provoca a ira de toda aristocracia local, fazendo com que 0 Visconde de Athaípe buscasse alternativas para punir o atrevido mestiço pela "afronta" e desmoralização que infligira à sua filha. Decidindo à revelia do Estado e da Justiça, ele ordena ao feitor que não mate o indivíduo, mas que antes o espancasse e o humilhasse perante todos os seus irmãos de cor e cativeiro. Seguindo as ordens à risca, o feitor Godofredo aplica uma forte "correção" no "petulante cavaleiro" e durante dias o espanca, soltando-o por fim, ordenando-o que jamais voltasse a Amparo.

Ainda em 1871, os nobres senhores de engenho de Amparo lamentam a assinatura da Lei do Ventre Livre e criam a "Liga da Lavoura" para defender os interesses dos proprietários da região. Em meio às discussões é que ocorre uma grande festa nos termos amparenses: a linda Augusta Leite, ainda humilhada pelo lamentável ocorrido da grande cavalhada, casa-se com Raul César, outro membro da elite local.

Após o casamento os nubentes são atacados por um grupo de quilombolas na chegada ao engenho onde morariam. No conflito os negros mataram o feitor Godofredo, o mesmo que havia espancado Nazário. O mestiço, por ironia do destino, havia se tornado líder do Quilombo. Um pedido frustrado de ajuda para o grande engenho da família revela mais uma ação "imperiosa" dos negros: eles haviam atacado a propriedade do Visconde e o "nobre senhor" apoplético, caiu numa crise que desembocou pouco tempo depois na sua morte.

Morto o visconde de Athaípe, abatida a coluna social de Amparo, a previsão dos males decorrentes desse novo desastre prostrou as outras vitimas da "Nêmeses negra" que as perseguia como uma obsessão:"mais mortos que vivos, os senhores de engenho encomendaram-se a Deus". 2 Nazário, por outro lado, vitorioso, passou a ser conhecido como o "flagelo dos senhores". Mais tarde, após a abolição e em tempos republicanos, se tornaria o novo chefe político de Amparo.

A narrativa contada acima poderia ter realmente acontecido na Bahia das últimas décadas do Império. Poderia, mas não aconteceu. Trata-se de uma das novelas do romancista baiano Xavier Marques (1861-1942).

2 MARQUES. Xavier. As voltas da estrada. Livraria Freitas Bastos (Antiga Leite Ribeiro), Rio de Janeiro, 1930. p. 195. 
Narrando uma história que se passa numa cidade com o sugestivo nome de "Amparo dos Cativos", Xavier Marques (1861-1942) apresenta uma comunidade que viu seu líder, o Visconde de Athaípe, tradicional senhor de engenho do Recôncavo, morrer justamente no período em que se dá o fim do "trabalho servil". Não obstante a morte do nobre senhor "coincidir" com o fim da instituição que abalizava seu estilo de vida, o autor descreve a crise do sistema escravista como um processo que se inicia com a resistência e os conflitos provocados pelos negros e com a aplicação das leis abolicionistas. Acrescenta ainda que a Lei do Ventre Livre provocou o acirramento dos ânimos entre senhores e escravos. Sem possuir mais nenhuma vantagem em manter as negras em suas posses, em virtude de suas "crias" não the serem mais rendosas, os proprietários mandam-nas embora e "enrijecem" o cativeiro sobre os negros. Em contrapartida, os cativos respondem com fugas, violência e morte. Em meio a pressões que partem dos negros e do governo, extingue-se o elemento servil.

Assim como Xavier Marques, Anna Ribeiro (1843-1930) tentou entender e representar o fim do escravismo na Bahia. Através da ficção ambos inscreveram suas versões do evento e também suas representações sobre seus egressos. Entretanto, o tom utilizado por Anna Ribeiro e a visão que ela nos oferece, se contrapõe as representações que nos trás Xavier Marques.

Construindo uma versão paternalista em suas narrativas, Anna Ribeiro, arquiteta tipos sociais representativos da visão do mundo senhorial em crise: escravos ingratos, senhoras que sofrem os reveses do abandono de suas mucamas, senhores vitimizados, um Estado "imprevidente" e uma Princesa "inconseqüente" por ter assinado uma lei que, "da forma que foi assinada, só trouxera infortúnios". A abolição na obra Ribeiriana é colocada como um fato isolado desprovido de tensões e conflitos e é imbuído de traumas e ressentimentos senhoriais. ${ }^{3}$ A hierarquização das raças é uma marca perceptível na representação infantilizada do negro e na superioridade do "civilizado" branco. Esse discurso compunha o universo da racialização

\footnotetext{
3 OLIVEIRA, Marcelo Souza. Fios literários na teia da História: paternalismo, escravidão e pós-abolição num romance de Anna Ribeiro. In: Revista Em Tempo de Histórias, Publicação do PPGHIS/UnB, n.11, Brasília, 2007. In: http://www.unb.br/ih/novo_portal/portal_his/revista/index.html, acesso em 08 de junho de 2009.
} 
preconizada pela ciência, que na Primeira República serviria como contraponto ideológico para tentar manter e perpetuar as relações de poder.

Em Letícia (1908), Anna Ribeiro de Araújo Góes Bittencourt (1843-1930) conta a História de Letícia, jovem, de fino trato, filha de um dos senhores de engenho mais poderosos do Recôncavo. Apaixonada por um abolicionista, mesmo contra a vontade do pai, a rapariga acaba se casando. Mudando-se para a Corte, pouco tempo depois é obrigada a voltar ao engenho do pai, pois o mesmo adoecera, por causa da rebeldia e das pirraças dos negros, excativos, segundo conta a narradora. É que se "operara o golpe do 13 de maio", cuja conseqüência seria a morte do mundo senhorial, algo metaforizado na morte do Sr. Travassos, o pai da protagonista. Sob o "novo regime", o velho senhor dizia "não haver mais lugar no mundo para um homem como ele".

Enquanto em Letícia, os senhores de engenho gozavam uma vida de "abastança" e "ostentação" cujo fim foi provocado por um "golpe" dado pelo governo da Princesa Isabel e "seus ministros", em As voltas da estrada a crise do sistema senhorial começa bem antes e vai se aprofundando à medida que os senhores baianos não conseguem adaptarem-se ao vindouro estilo de vida, que traria à voga a mão-de-obra livre.

Trata-se de dois enfoques sobre a mesma época, mas que partem de olhares distintos. Os dois romancistas viveram e recontaram as experiências da decadência senhorial baiana, entretanto, os lugares sociais conferidos a cada um, contribuíram para que eles oferecessem ao leitor duas visões peculiares. A primeira, de uma ex-senhora de engenho que testemunhou a própria crise nas posses da sua família, uma das mais tradicionais do Recôncavo. A segunda versão é narrada por alguém que viveu os ímpetos do abolicionismo e declarava-se como um deles. Duas formas de contar o mesmo processo histórico sob o viés literário: o declínio do escravismo e a situação dos negros no pós-abolição. Duas representações distintas do mesmo período Histórico. Tratamentos diferentes para um tema similar.

\section{O pós-abolição na Bahia: um breve balanço historiográfico}

O contexto vivido tanto por Anna Ribeiro, quanto por Xavier Marques foi o da Primeira República. Esse período coincidiu com o pós-abolição que trouxe para os negros, outrora, escravos, a condição de cidadãos. Na Bahia, as 
discussões em torno dessa nova condição dos africanos e afro-brasileiros foi marcado por grandes conflitos que foram tratados também no campo da memória - recente - do escravismo. Esse contexto também foi marcado pela racialização "cientifica" das formas com que esse novo cidadão seria tratado. Sob essa realidade, os autores escreveram seus romances e neles imprimiram as formas com que representavam a realidade.

Nos últimos anos, vários estudos têm sido publicados sobre a Bahia no período pós-abolição. Em artigo publicado pela revista baiana Afro-Ásia, intitulado "Libertos do 13 de maio e os ex-senhores na Bahia: conflitos no pósabolição" lacy Mata afirma que a violência perpetrada aos escravos no interior da Bahia sugere que a escravidão nas lavouras baianas, às vésperas da abolição, ainda se mantinha com algum vigor. Não apenas a produção de açúcar estava baseada fundamentalmente no trabalho servil, mas também a autoridade senhorial sobre o escravo e a legitimidade do castigo parecia sobreviver, apesar dos abalos sofridos com as ações escravas. Para a autora 0 13 de maio, na Bahia, não significou apenas o reconhecimento de um fato consumado; alguns escravocratas baianos recusaram-se a crer que a lei abolira imediata e incondicionalmente a escravidão. Diferentemente das leis de 1871 e 1885, referentes à propriedade escrava, o decreto de 13 de maio fora aprovado às pressas, não tendo sido objeto de muitas discussões. O choque destes senhores não se restringiu à aprovação da lei; referiu-se também às atitudes de autonomia e independência que os libertos assumiriam logo após a abolição. ${ }^{4}$ A autora destaca ainda que mesmo tendo a ciência da emergência da Lei que viria a libertar os negros no Brasil em questão de tempos, os exsenhores baianos foram, em sua maior parte, pegos de surpresa com uma Lei aprovada as pressas sem muitas discussões.

Assim, aprovada à revelia dos senhores do Recôncavo, a Lei não considerou suas principais reivindicações: indenização aos antigos proprietários; abolição lenta e "gradual"; e um processo que, pelo menos aparentemente, adviesse das mãos dos próprios senhores. Essa última "exigência" garantiria, pelo menos em tese, o agradecimento dos negros, o que fortaleceria mesmo depois da liberdade as relações paternalistas entre

${ }^{4}$ MATA, lacy Maia. Libertos do 13 de maio" e ex-senhores na Bahia: conflitos no pós-abolição. Afro-Ásia. n 35 . pp. 163-198. Salvador, 2007. p. 171. 
dominadores e dominados. lacy Mata ainda ressalva que a liberdade, para os ex-cativos, esteve dotada de muitos significados: a possibilidade de movimentar-se sem a necessidade de autorização do ex-senhor; o fim dos castigos corporais, a escolha e como e em que tempo trabalhar. Assim o pósabolição na Bahia esteve marcado por violência entre senhores e escravos, invasões de propriedade, roubos praticados pelos recém-libertos, e até mesmo suicídios de ex-senhores que não sabiam o que fazer com a lavoura sem a mão-de-obra escrava para trabalhá-la.

Em Encruzilhadas da liberdade, Walter Fraga Filho acompanha trajetórias de escravos e libertos dos engenhos do Recôncavo, entre as últimas décadas que antecederam a abolição em 1888, e as que a sucederam. Segundo ele, o recorte oferece a oportunidade de avaliar conseqüências e implicações da abolição sobre uma região que abrigou uma das mais duradouras sociedades escravistas das Américas. ${ }^{5}$ Fraga Filho também considera a produção das memórias de ex-senhores e ex-escravos que deixaram seus registros nas décadas seguintes ao 13 de maio. Entretanto, ele não aprofunda a análise destas fontes, visto que, investiga as trajetórias de negros nos engenhos do Recôncavo, nas últimas décadas da escravidão. Por esse motivo, a abordagem que ele faz da temática do 13 de maio é tangencial e lacunar, visto que seus objetivos eram outros.

Os comentários de Fraga Filho oferecem um elo entre a interpretação sobre 013 de maio, conferida pelos historiadores baianos do início do século XX e a Nova Historiografia da Escravidão na Bahia. Enquanto os primeiros defendiam a idéia de que o 13 de maio era uma espécie de "divisor de águas", uma ruptura com uma Era, os segundos coadunam com as idéias defendidas por Silvio Humberto dos Passos Cunha, quando afirma que a continuidade da crise da economia açucareira baiana nesse período envolveu diversas ordens de fatores, entre eles a incapacidade crônica das oligarquias açucareiras de criar as condições para o soerguimento da lavoura de cana e a disputa entre as

${ }^{5}$ FRAGA FILHO, Walter. Encruzilhadas da liberdade: histórias de escravos e libertos na Bahia (1879-1910). Campinas, SP: Editora da Unicamp, 2006. p. 23. 
frações do capital baiano em torno da sucessão política e econômica dessas oligarquias. $^{6}$

Wlamyra Albuquerque em $O$ jogo da dissimulação intenciona perceber a articulação entre a questão racial e o desmonte do escravismo no Brasil. Com o recorte temporal focado nas últimas décadas oitocentistas, a autora reconstrói algumas tramas em que tiveram envolvidos vários sujeitos históricos que se tornam emblemáticos dentro da sua pesquisa. Para instrumentalizar a sua análise, a ela ainda na introdução faz reflexão sobre o conceito de raça, categoria central para a compreensão da sua pesquisa. Ela ressalva que, sendo um conceito de raça construído historicamente, o século XIX, se marcou pela emergência do discurso que passava a conhecer no negro um "outro", biológica e culturalmente inferior. Nesse sentido, a racialização das relações sociais no mundo moderno revelava uma política de exclusão e acomodação, fundamentada em premissas biológicas e na sedimentação do discurso da supremacia branca.

Albuquerque parte da idéia de que no Brasil, o processo emancipacionista foi marcado pela profunda racialização das relações sociais; nesse sentido, houve a manutenção de certos esquemas hierárquicos foi o principal saldo do longo e tortuoso percurso que levou a sociedade brasileira à extinção legal do cativeiro em 1888. Por último, ela tenta explicitar como ações políticas protagonizadas por diferentes instituições, a partir da suas perspectivas e planos para pós-emancipação, racializavam a sociedade naquele momento. Para responder essas premissas, a autora, recorre a quatro episódios ocorridos entre 1877 e 1898, que deram visibilidade ao sutil jogo de demarcação de lugares e preservação de privilégios sociais e políticos a partir de critérios raciais. O capítulo que nos interessa aqui, em particular, intitulado "Não há mais escravos, os tempos são outros: abolição e hierarquias raciais no Brasil" discute a abolição na Bahia. Tratando o processo emancipacionista como uma janela através da qual se pode ver "os contornos de certos modos de compreender e experimentar mudança", a Albuquerque partiu da desconfiança, que ela afirma ser evidente, de que concepções e limites de

${ }^{6}$ CUNHA, Silvio Humberto dos Passos. Um Retrato Fiel da Bahia: sociedade-racismo-economia na transição para o trabalho livre no Recôncavo açucareiro, 1871-1902. UNICAMP, (Tese de Doutorado em Economia), 2004. p. 125. 
cidadania negra, noções de diferenciação racial e mesmo memórias do passado escravo estariam em circulação, no ano de $1888 .^{7}$

Como já mencionei, foi nesse contexto que viveram Anna Ribeiro e Xavier Marques. Ambos viveram as últimas décadas da escravidão no Brasil e as primeiras décadas republicanas. Tanto a primeira, quanto o segundo procuraram dar sentido através da arte literária a essas experiências. Porém, algumas distinções em suas obras revelam que os lugares sociais desses autores indicam as formas antagônicas com que representam a escravidão e o pós-abolição na Bahia.

\section{Um abolicionista e uma senhora de engenho: os autores em contexto}

Xavier Marques, jornalista, político, romancista, poeta e ensaísta, nasceu na ilha de Itaparica, BA, em 3 de dezembro de 1861, e faleceu em Salvador, BA, em 30 de outubro de 1942. Eleito em 24 de julho de 1919 para a Cadeira $n$. 28, na sucessão de Inglês de Sousa, foi recebido em 17 de setembro de 1920, pelo acadêmico Goulart de Andrade. Sua ficção é das mais representativas na área regionalista e praieira baiana, a cujos valores permaneceu sempre fiel. Publicou também volumes de poesia, de linguagem parnasiana, coletâneas de contos e ensaios. Alcançou vários prêmios literários em sua longa vida de escritor, entre os quais um prêmio da Academia Brasileira de Letras, em 1910, pelo romance Sargento Pedro. Gozou de grande prestígio na Bahia, onde vivia como um patriarca literário, cercado de consideração, respeito e amor de todos. Entre sua vasta produção destacam-se os romances: Uma família baiana (1888); Boto e companhia (1897); Jana e Joel (1899); Pindorama (1900); Holocausto (1900); Praieiros, edição conjunta das novelas Maria Rosa e $O$ arpoador e mais $A$ noiva do golfinho (1902); O sargento Pedro (1910); $A$ boa madrasta (1919); A cidade encantada (1919); O feiticeiro (1922); As voltas da estrada (1930).

Militante da causa abolicionista nos tempos do Império, nos anos que se seguiram a República, foi deputado, pelo Partido Republicano. Sobre isto,

${ }^{7}$ ALBUQUERQUE, Wlamyra R. de. O jogo da dissimulação: abolição e cidadania negra. São Paulo: Companhia das Letras, 2009.p. 36-41. 
Paulo Santos Silva assevera que "as letras provinciais e a política republicana registravam, em Xavier Marques, mais um caso de sedução recíproca". ${ }^{8}$ Tanto a causa abolicionista, quanto à republicana marcaria indelevelmente a obra deste autor.

As obras de Xavier Marques estão marcadas por uma produção local que se distancia do centro de produção literária, o Rio de Janeiro da época. Para Jorge Araújo, o autor "transfigura o pitoresco e a cor local, imprimindoIhes uma representação artística que ultrapassa a mera estilização"9 Araújo destaca ainda que o regionalismo de Xavier Marques não se restringe apenas ao "estilo pictórico" característico de Afrânio Coutinho, mas abrange a sensibilidade coletiva, ressumando os assuntos da comunidade cultural, tornando evidentes os costumes, lendas, mitos, tipos, linguagens, em suma a personalidade coletiva da sua região. Neste sentido, para Jorge Araújo, Xavier Marques é modelo considerável, uma vez que não transige com a mediocracia dos valores autóctones, identificados com orgulho e complacência apenas por serem autóctones. Ele ressalva ainda que,

[...] o romancista realiza um profundo mergulho na realidade local, captando-Ihes símbolos de efetiva permanência existencial e estética, revigorados pela sincera singularidade do tom local e suas raízes, conquanto resvale no rigor axiomático, documental e lingüístico ${ }^{10}$.

Pedro Calmon o define como "homem regional, que se limitava a ser fiel à Bahia aos seus costumes vestidos de tradição e harmonia". ${ }^{11}$ A Bahia, segundo os críticos da época, está por inteiro na obra de Xavier Marques, a ponto de ser considerado por Afrânio Coutinho "como símbolo da alma baiana, talvez nenhum artista no Brasil - a não ser Machado de Assis para o meio carioca possua tanta afinidade com o seu povo a ponto de ser apontado com sua imagem total". Sua produção abrange desde a paisagem da Cidade da Bahia e seu Recôncavo, descrevendo personagens pertencentes à classe alta e média urbana, como também, ainda que de forma enviesada, a presença de personagens de descendência africana, de vida praieira, e o ciclo de cana-de-

\footnotetext{
${ }^{8}$ SANTOS, Paulo Silva. Âncoras de Tradição: luta política, intelectuais e construção do discurso histórico na Bahia, Salvador: EDUFBA, 2000. pp. 111-112.

9 lbid., p. 12.

10 Ibid., p. 13.

${ }^{11}$ CALMON, Pedro. Discurso do senhor Pedro Calmon. Revista da Academia Brasileira de Letras. [S/N], São Paulo, 1942. p.137.
} 
açúcar na Bahia. Assim, sua obra pode ser lida como um projeto literário que contribui para interpretação da Bahia desde o final do século XIX até início do século $X X^{12}$.

A Bahia nesse período - ou melhor, a intelectualidade da Bahia nesse período - sentia-se diferente por não acompanhar o ritmo de modernização que acontecia no sul, por ter no seu passado histórico a luta pela Independência do País, e por ter perdido o estatuto de capital para o Rio de Janeiro. Esses fatores históricos contribuiriam para a articulação da intelectualidade local, no sentido de individualizar a Bahia no conjunto brasileiro de civilização, posicionamento que ressoará na narrativa de Xavier Marques ${ }^{13}$.

Nascida em Itapicuru, Anna Ribeiro de Araújo Góes Bittencourt ${ }^{14}$ viveu desde os sete anos nos arredores da cidade de Catu no Recôncavo baiano. A sua realidade foi bem típica de uma sociedade patriarcal e agrária: escravos, engenhos, barões (era sobrinha e prima de três dos mais poderosos e abastados da região). Esposa do médico e senhor de engenho Sócrates Bittencourt, primeiro Intendente de Santana do Catu, dedicada esposa, empenhou-se em cuidar de seus três filhos, de seu pai e dos serviços domésticos junto aos dos escravos. Anna Ribeiro pode ser considerada uma típica representante da elite feminina do Recôncavo baiano no século XIX.

Escritora detalhista dedicava-se a produzir textos para as jovens "sinhazinhas" de seu tempo. Anna Ribeiro escreveu aproximadamente dezessete artigos para vários periódicos da época, destacando-se o Almanaque de Lembranças Luso-brasileiro e a Paladina do Lar. A sua obra é vasta e diversificada e pode ser classificada da seguinte forma: romances sagrados - A Filha de Jephté (1882) e Abigail (1921) - e romances profanos O anjo do perdão (1885), Helena (1901), Lúcia (1903), Letícia (1908) e Suzana (Inédito). Anna Ribeiro também produziu um livro de memórias intitulado

\footnotetext{
12JESUS. Liliane Vasconcelos de. Xavier Marques: interprete da Bahia na virada do século. In: Encontro Regional da ABRALIC: Literaturas, Artes, Saberes, São Paulo, 2007. pp. 2-3.

13 Idem.

14 A família Araújo Góes é uma das mais antigas e tradicionais da Bahia. Seu fundador português, Gaspar de Araújo, originário da vila de Arcos de Val-de-Vez, no Minho, e sua Mulher Dona Catarina de Góes, procedente da vila de Alemquer, perto de Lisboa, se instalaram em 1561 na Capitania de llhéus. A partir de - 1800-1810 - uma de suas descendências [Simeão de Araújo Góes] se destaca na política e economia de Salvador e do Recôncavo. Três de seus membros foram "agraciados" com títulos de baronato no decorrer do século XIX, período de ascensão econômica e social dessa família. (MATTOSO, Kátia M. de Queirós. A opulência na província da Bahia. In: ALENCASTRO, Luiz Felipe de. História Privada do Brasil. São Paulo: Companhia das Letras, 1997. Vol. 02).
} 
Longos Serões do Campo (1992). Além de quatro manuscritos na área da crítica literária. Recentemente, foram localizadas mais algumas publicações da autora: Lúcia, Violeta e Angélica e Marieta; o primeiro foi um romance publicado no jornal $A$ Bahia (1903), e os dois últimos são contos publicados no Jornal de Noticias (1906 e 1908). Os romances de Anna Ribeiro têm um valor pedagógico, pois neles as histórias têm a função de mostrar às jovens a necessidade de conservar os "valores e os bons costumes" através de lições de moral explicitamente evocadas em seus escritos. As personagens de Anna Ribeiro têm quase sempre como protagonistas moças que vivem entre as calúnias contra sua honra, o fracasso econômico familiar e a defesa dos valores morais ${ }^{15}$.

A obra destes dois literatos baianos vem aqui neste estudo se entrecruzar em virtude da comparação de duas de suas obras cuja temática é a mesma e abordagem distinta. Embora a diferença de publicação entre Letícia e As voltas da estrada seja de vinte de dois anos, os autores foram contemporâneos, viveram praticamente na mesma época. Os enredos constroem-se em torno do mesmo período histórico e da mesma região: o Recôncavo baiano pré e pós-abolição. Entretanto, as narrativas transcorrem em direções diferentes no que tange a visões de mundo diferentes, o que evidencia as diferenciações quanto a suas posições sociais e quanto aos papéis históricos exercidos por ambos.

\section{Entreato teórico}

Segundo Sidney Chalhoub, refletir sobre a literatura na perspectiva da história social significa, já de início, adotar um pressuposto necessariamente materialista. Ele assevera que em uma proposta de pesquisa desta natureza deve se historicizar a obra literária, inserindo-a no movimento da sociedade, investigando as suas redes de interlocução social e destrinchando não só a sua suposta autonomia em relação a sociedade, mas a forma como esta representa e reconstrói a sua relação com a mesma. Para Chalhoub, autores e obras literárias são testemunhos históricos, pois são acontecimentos datados,

${ }^{15}$ Sobre a vida e a obra de Anna Ribeiro ver OLIVEIRA, Marcelo Souza. Uma senhora de engenho no mundo das letras: o declínio senhorial na obra de Anna Ribeiro. (Dissertação de Mestrado em Estudo de Linguagens/UNEB). Salvador, 2008. OLIVEIRA, Marcelo Souza. Memórias de uma senhora de engenho lembranças e esquecimento nos Longos Serões do Campo de Anna Ribeiro. In: Patrimônio e Memória. São Paulo, 2008. 
historicamente condicionados, valendo pelo que expressam aos seus contemporâneos. ${ }^{16}$

Sobre isto, o autor chama atenção para duas observações pertinentes que merecem destaque: no primeiro, de acordo com ele, a questão central não é o caráter manifestamente ficcional ou não de determinado testemunho histórico - neste caso a literatura -, mas a necessidade de destrinchar sempre a especificidade de cada testemunho. Cabe o mesmo interrogatório sobre as intenções do sujeito, sobre como ele representa para si mesmo a relação entre aquilo que diz e o real, cabe desvendar aquilo que o sujeito testemunha sem ter a intenção de fazê-lo, investigar as interpretações ou leituras suscitadas pela intervenção do autor, enfim, é preciso buscar a lógica social do texto. Segundo, se a literatura não transcende a sua época, é preciso perceber as características específicas da fonte literária. É necessário levantar questões ligadas ao tipo de literatura, suas características e como o autor concebe a sua arte. O objetivo com isso é inserir autores e obras literárias específicas em processos históricos determinados. ${ }^{17}$

Nesse contexto cabe tentar entender como Xavier Marques vê a literatura e quais funções que ele atribuiu a ela. $O$ autor afirma que das criações do homem culto nenhuma a excede em expressão, como verdadeira imagem moral da sociedade, quanto à literatura. No discurso de inauguração da Academia de Letras da Bahia, ele afirma que:

[...] os sentimentos, idéias, fantasia, caráter, tudo o que há de essencial, profundo, invisível, inconsciente na raça, ela guarda, concentra, reflete e perpetua. Por isso um dos espíritos mais vastos que no século XIX se aplicaram ao estudo da literatura estimativa preferível, na reconstrução psicológica de uma época a quaisquer outros documentos, um grande poema ou um belo romance. ${ }^{18}$

Para o romancista, a obra ficcional "perpetua" os sentimentos e idéias do autor por meio da "fantasia", ou seja, de sua criatividade. Pautado nesse prisma e ancorado na construção de tipos sociais que mais retratassem os mais variados modelos vigentes no processo de declínio do mundo senhorial, o autor vai dar um caráter peculiar a sua obra, demonstrando a visão de um ex-

\footnotetext{
${ }^{16}$ CHALHOUB. Sidney e PEREIRA, Leonardo. (org.), História Contada. Rio de Janeiro, Nova Fronteira, 1998. p. 7.

17 Id. Ibid. p. 8 e 9.

18 MARQUES, Xavier. Discurso pronunciado pelo acadêmico Xavier Marques na sessão pública de 10 de abril de 1917. In: Revista da Academia Brasileira de Letras. Vol. I. p. 78. Imp. Oficial do Estado, Salvador, 1930.
} 
abolicionista, sobre o processo da abolição e, na mesma medida, também coloca a questão racial e da cidadania negra em discussão, ao construir "fantasiosamente" personagens negros e mestiços que agem como cidadãos e, mais que isso, que exercem liderança política efetiva dentro de suas tramas. Quanto aos brancos, os [ex]senhores destaca a sua degradação moral, em virtude da contaminação pelo escravismo.

Já Anna Ribeiro enxerga a escravidão sob o ponto de vista dos senhores. Seu projeto literário era voltado para a orientação moral das jovens senhorinhas e nele é nítido o tom paternalista típico da ideologia senhorial. ${ }^{19}$ Nancy Rita Vieira Fontes afirma que Anna Ribeiro produziu ao longo da sua carreira no mundo das letras um projeto literário que tinha três objetivos básicos: construir um romance para mulheres; o intuito de escrever romances que tivessem um caráter formativo; e criar uma obra que enfatizasse aspectos da realidade baiana. $^{20}$ Nas histórias ficcionais da romancista focam-se situações onde as famílias senhoriais têm de se adaptar às mudanças verificadas na sociedade baiana no período de decadência da cultura canavieira e do processo abolicionista.

É paradoxalmente esta intensa "aparência" de realidade que revela a intenção ficcional ou mimética em Anna Ribeiro. ${ }^{21}$ Assim, permanece a reinterpretação dada por ela nas suas escrituras, procurando dar "tons reais" a uma obra imaginada a partir de sua realidade de vida. A própria Anna Ribeiro menciona esta questão quando afirma na dedicatória feita à sua prima Mariotti de Araújo Góes, em Letícia: “Acharás, porém, princípios de sã moral, bons exemplos tirados de fatos, nem todos imaginários e sim colhidos na experiência e observação". 22

Antonio Cândido considera que na ficção em geral, também na de cunho trivial, o raio de intenção dirige-se à camada imaginária, sem passar diretamente as realidades empíricas possivelmente representadas. ${ }^{23}$ As

\footnotetext{
19 OLIVEIRA. Marcelo Souza. Uma Senhora de engenho no mundo das letras: o declínio senhorial em Anna Ribeiro. EDUNEB, Salvador, 2009.

20 FONTES, Nancy Rita Vieira. A bela esquecida das letras baianas: a obra de Anna Ribeiro. (Mestrado em Letras/UFBA), Salvador-Ba, 1995.. p. 78.

${ }^{21}$ CÂNDIDO, Antonio. ROSENFELD, Anatol. PRADO, Décio de Almeida. GOMES, Paulo Emilio Salles. Personagem de ficção. Coleção Debates, $7^{\text {a }}$ ed. São Paulo: 1968.. p. 20

22 BITTENCOURT, Anna Ribeiro de Araújo Góes. Letícia. Litho-Typ. E Encadernação Reis \& Cia. Salvador, 1908. p. III.

${ }^{23}$ CÂNDIDO, Op. cit., p. 42.
} 
questões que concernem ao imaginário como suporte para composição das narrativas literárias têm relevância nodal para se tentar apreender as formas de ver e de sentir o mundo. O vínculo entre o autor e a sua personagem estabelece um limite à possibilidade de criar, à imaginação de cada romancista, que não é absoluta, nem absolutamente livre, mas depende dos limites do criador. ${ }^{24}$ Ou seja, o imaginário dos indivíduos é engendrado por uma série de experiências e discursos inerentes à realidade do autor.

Sandra Pesavento lembra que o imaginário deve ser percebido como um dinamismo organizador, dinamismo este que se converte em fator de homogeneização da representação. ${ }^{25}$ Longe de ser mera reprodução ou espelho da realidade, ela é em si elemento de transformação do real e de atribuição de sentido ao mundo. Faz parte ainda de um campo de representação e, como expressão do pensamento, manifesta-se por imagens e discursos que pretendem dar uma definição da realidade.

Nesse contexto, pode-se perceber que os lugares sociais de Anna Ribeiro e de Xavier Marques serão de suma importância para a compreensão das formas como estes representam a escravidão, a liberdade e a cidadania dos negros libertos após do 13 de maio. Em certa medida quando eles escrevem inserem, as vezes sem ter a intenção, o imaginário e as experiências de seus respectivos grupos sociais.

\section{Os romances: literatura e memórias da abolição}

Letícia, romance publicado em 1908, é a obra mais completa de Anna Ribeiro, pois sintetiza o auge, a crise e a decadência do mundo senhorial. A história começa no ano de 1887, quando a jovem Letícia tenta convencer o seu pai, o velho Travassos, do seu casamento com o jovem advogado da Corte, Eurico. Como todas as obras da autora, o palco da trama é mais uma vez o Recôncavo baiano do final do século XIX.

Letícia é uma moça bela, filha de um "abastado" senhor de engenho, mas que era "exaltada" por causa de leituras impróprias para a uma moça de sua idade. O "espírito romanesco" da jovem a faz se apaixonar por um jovem

\footnotetext{
24 Idem, p. 68.

25 PESAVENTO, Sandra Jatahy. Em busca de uma outra história: imaginando o imaginado. Revista Brasileira de História, Vol. 15, nº. 29, ANPUH; Contexto, São Paulo: 1995, p. 17
} 
carioca. Eurico era um abolicionista radical, advogado, dado aos vícios, jogatina e filho de um pai de mesma índole. Ele conhece Letícia em uma badalada festa no Rio de Janeiro. Mesmo com a oposição do Velho Travassos, Letícia se casa com Eurico e vai morar no Corte. A moça acaba sofrendo com as traições do marido e com o fato de não se julgar à sua altura, visto que fora "uma jovem criada no campo", enquanto o rapaz é um típico homem da cidade.

Os infortúnios do velho Travassos começam após o 13 de maio: "Os estadistas que levaram a princesa a dar este golpe nem ao menos cogitaram da época em que seria menos conveniente" ${ }^{26}$. Na narrativa ficcional de Anna Ribeiro, a potência do "golpe" teria levado o engenho dos Travassos à sua derrocada final. Após o ato imprevidente da Princesa e seus ministros, os senhores de engenho, lastimam-se pela ingratidão dos escravos:

\begin{abstract}
É impossível viver assim! Nunca pensei que nossos escravos, sendo tão bem tratados, nos deixassem com tanto desapego. Sempre ouvi dizer que a escravidão traz vileza, mas eu muitas vezes respondia a essa máxima que julgava sediça (sic) com a frase da autora da Cabana do Pai Tomás: "Tratem-nos como cães e eles vos tratarão como cães e eles procederão como cães: tratem-nos como homens e eles procederão como homens". Mas qual! [...] Quando Ihes comuniquei que eram livres, disse-lhes: os que não quiserem ficar comigo podem retirar-se; não Ihes guardo por isso rancor; só lhes exijo eu me previna para poder guardar o trabalho. Todos protestaram não me deixar; alguns acrescentaram: "Ainda que meu senhor nos tanja, eu não saio; aqui hei de morrer. Nós não tivemos senhor, e sim pai. ${ }^{27}$
\end{abstract}

A surpresa do comportamento do senhor diante da mudança dos escravos e a patente ineficácia das formas tradicionais de mando senhorial são patentes. Ele destaca também a ótica paternalista do senhor frente ao comportamento dos ex-escravos. Entretanto, algumas outras questões podem ser tiradas desse episódio. O senhor achou que foi o primeiro a thes comunicar sobre a liberdade. Segundo, o velho Travassos afirmou que não guardaria nenhum "rancor" aos que quisessem partir. Terceiro, e talvez mais importante, foi a dissimulação dos ex-cativos ante ao senhor: "Ainda que meu senhor nos tanja eu não saio, não tivemos senhor e sim pai”. Essas três questões nos ajudam a entender melhor qual seria a tal ingratidão, da qual os senhores dos engenhos do Travassos reclamavam. Em outro trecho o senhor continua a reclamar do comportamento dos ex-cativos:

\footnotetext{
${ }^{26}$ BITTENCOURT. Letícia. Litho-Typ. E Encadernação Reis \& Cia. Salvador, 1908. p. 169.

27 Ibid., p. 68.
} 
Ora, marco um dia para moagem; aviso a todos; estão os picadeiros cheios de canas; chego ao engenho, faltam alguns; onde estão? Mudaram-se sem dar-me a menor satisfação. Há quem sofra isto com paciência? Manhas, falsidades, como que com propósito de fazer pirraça ${ }^{28}$.

Uma doença contraída pelo Velho Travassos faz com que sua filha retorne para o interior da Bahia. A tal doença é atribuída à "rebeldia e à ingratidão" dos ex-escravos. Sozinho, o já idoso proprietário havia convidado seu genro a assumir os negócios da família, mas ele rejeitou, afirmando que não tinha jeito para a vida no campo. Enquanto Letícia cuidava do pai, Eurico mantinha um caso amoroso com Edelvira, uma atriz, com quem tem um filho. A situação precária do casamento dos jovens e a morte do Sr. Travassos provocam o "amadurecimento" de Letícia, que vende a propriedade do pai e vai morar na ilha de Itaparica.

Abandonado por Edelvira, Eurico retorna para a Bahia onde fica doente e recebe os cuidados de sua esposa, mas ela não faz as pazes com ele até ver o seu arrependimento, o que por fim acontece. Casamento restaurado, os dois reatam os laços de amor. Em meio à história de Eurico e Letícia é discutido o processo da abolição da escravatura e apresentado alguns embates de idéias entre escravocratas e abolicionistas e a sorte de alguns personagens que viveram esse processo.

Em As voltas da estrada, Xavier Marques conta a história do mestiço liberto Nazário Ribeiro, filho do senhor de engenho Luiz Ribeiro com uma negra escrava. Para isto, o autor divide a narrativa em duas partes: a primeira decorre na cidade fictícia de Nossa Senhora do Amparo dos Cativos, situada no Recôncavo baiano no ano de 1871, ano em que foi assinada a Lei do Ventre Livre. A segunda parte se passa no ano de 1900, quando Amparo dos Cativos já vivia outra época pois, "já era finda a era dos senhores de engenho".

Ainda em 1871, o jovem Nazário Ribeiro participa de uma cavalhada, festa tradicional da cidade de Amparo. A cidade então vivia seu auge, e os senhores de engenho eram os donos de tudo e de todos, o que se evidencia na pessoa do grande chefe político local: João Luiz Vasconcelos de Bastos Leite, o visconde de Athaípe. O visconde era proprietário de um dos maiores engenhos da região e dono de numerosa escravaria. Em sua primeira 
descrição, o autor o descreve como "o chefe de indiscutível ascendência na comarca" 29.

Pai de Augusta Leite, uma das moças mais lindas da região, moça de fino trato, disputada pelos melhores partidos de Amparo, o visconde se surpreende quando presencia juntamente com a elite de toda a comarca a vitória na cavalhada do homem mascarado que oferece os louros da vitória a sua filha. O motivo da surpresa de todos é a identidade do vencedor: o mestiço Nazário.

Completamente enfurecido pelo ocorrido, o visconde exige uma solução do delegado e do juiz local, dois homens que ocupavam cargo por indicação sua. Entretanto, como não tinha praticado crime nenhum, o nobre se recusa a aceitar a sugestão de seus comandados de enquadrar o rapaz em outro crime. Resolve então que para lavar a honra de sua filha, mandaria seu feitor, um homem violento chamado Godofredo. Capturado pelo feitor e seu bando, o jovem sofre uma sessão de tortura que dura quinze dias, sendo que nos momentos de "descanso" o amarram no tronco de cabeça para baixo. Na surra de Nazário "a escravaria testemunhou bestificada mais um quadro da sua vida"30. Segundo o autor, o mestiço "sentia saudades do cativeiro, compreendendo a irrisão dessa liberdade. E chorou profusamente, chorou, soluçou como um menino abandonado, com fome e frio" ${ }^{31}$. Logo depois do castigo, foi solto com roupas feitas com "algodão cru dos negros", e intimado a sumir daquela comarca para nunca mais aparecer.

Sob o calor dos acontecimentos a nobreza Amparense é surpreendida pela notícia, pois nesse momento é assinada e Lei do Ventre Livre, em relação a qual João de Lima afirmou - "É a morte da lavoura... é a miséria... Um horror". ${ }^{32}$ O Pânico dos senhores moços se reflete bem nas palavras de Leite Junior quando ele afirma que enquanto outros procuraram ser bacharéis "como os manos na Paulicéia" o seu pai preferiu obrigá-lo a ser senhor de engenho, e aprender no máximo como "se descasca um negro atrevido". ${ }^{33}$

\footnotetext{
29 MARQUES. Xavier. As voltas da estrada. Livraria Freitas Bastos (Antiga Leite Ribeiro), Rio de Janeiro, 1930. p. 17.

30 Ibid., p. 94.

31 Ibid., p. 98.

32 lbid., pp. 113-114.

33 Ibid., pp. 115.
} 
Embora a primeira parte destine-se ao decreto da decadência senhorial em decorrência das leis abolicionistas e das revoltas e levantes resultantes na formação do Quilombo liderado por Nazário, a estrada da vida ainda daria mais algumas voltas, pois em 1900, Nossa Senhora do Amparo teria outros donos: a família chefiada por Nazário Ribeiro. No excerto seguinte, o autor salienta mudança ocorrida na cidade:

\begin{abstract}
Doze anos apenas, a contar da abolição da escravatura e da imediata fundação da República, foram bastante para liquidar os remanescentes da rica e poderosa classe. Mortos os grandes proprietários, o intenso movimento abolicionista provou a incapacidade dos herdeiros para arcarem com a crise da lavoura e da indústria sacarina. Uma e outra soçobraram com a escravidão.

Os aspectos da vida eram profundamente estranhos aos poucos, já envelhecidos, que conheceram um regime por eles julgado a forma definitiva e única legítima de coexistência social. Para estes já não havia glória em viver. Tudo era tristeza, vergonha, decadência. ${ }^{34}$
\end{abstract}

Havia entre os de cor uns que souberam se aproveitar melhor da ruína dos senhores de engenho, entre eles um sexagenário, por nome Nazário Ribeiro. "Sem luxo escrupuloso, ganhou dinheiro, aumentou os seus rebanhos de bovinos e adquiriu aos herdeiros dos arruinados, por preços vis, extensas terras e prédios urbanos, quase todos onerados de hipotecas"35. Havendo tomado a defesa dos mais fracos ganhara também 0 respeito $\mathrm{e}$ reconhecimento do povo. Ficou tão rico e poderoso que, segundo o narrador: "Nazário Ribeiro tinha que subir. E subiu tão alto que das vicissitudes da época foi o caso típico pelo qual mediam o seu infortúnio os sobreviventes da nobreza decaída"36. O mestiço liberto tornou-se ainda o diretor político da comarca. Nazário residia na casa outrora pertencente ao Barão do Cerro [pai de Cirino Rocha].

Pastora, filha de Nazário, em virtudes dessas voltas dadas pelo destino, acaba se apaixonando por Paulino, filho de Augusta Leite. A resistência da mãe ao casamento do filho com pessoas de tão "baixa qualidade" e que ainda eram os responsáveis, segundo ela, pela desgraça de sua família foi um empecilho a ser superado pelo casal, que ao fim casam-se e promovem a "cura de velhas feridas".

\footnotetext{
34 Ibid., pp. 199-200.

35 lbid., p. 201.

36 lbid., p. 201.
} 


\section{Escravidões e Liberdades: historiografias, literaturas e representações}

A diferença entre a situação do negro dentro da escravidão e fora dela, é discutida, na concepção do autor, algumas décadas depois. Em As voltas da estrada, "a escravaria testemunhou bestificada mais um quadro da sua vida", ao perceber as surras aplicadas pelo feitor Godofredo no liberto Nazário. ${ }^{37}$ Após quinze dias, várias vezes preso no tronco de cabeça para baixo, e muitas chicotadas depois, o liberto já estava em "carnes vivas" e sua altivez anterior, já tinha dado lugar ao desespero. O mestiço então "sentia saudades do cativeiro, compreendendo a irrisão dessa liberdade. E chorou profusamente, chorou, soluçou como um menino abandonado, com fome e frio". ${ }^{38}$

As discussões suscitadas pelas poesias e pela prosa de Marques levamme a pensar nas condições que envolveram a cidadania negra entre os fins do Oitocentos e principio do Novecentos. Só lembrar que décadas depois Nazário, já como líder político de Amparo, afirma em alto e bom som: "Os tempos são outros. Hoje tudo é um. Tão bom como tão bom". ${ }^{39}$ A expressão pronunciada pelo personagem sugere que Marques construiu ume metáfora que reforça os ideais de cidadania negra na República, como superior a aquela que fora proposta a passos "graduais" na Monarquia.

Mas essa visão seria dissonante das versões dominantes. Em quanto a maior parte da produção intelectual do período transcorre para uma visão paternalista dos fatos, pautados em pseudo-discursos científicos, históricos e também empíricos, o autor partirá de pressupostos discordantes das posições e representações que seus colegas letrados assumiam. Só lembrar-se da já mencionada, Anna Ribeiro, ou mesmo de historiadores como Brás do Amaral e Pedro Calmon. ${ }^{40} \mathrm{E}$ seu livro História da Bahia: do Império à República, o Braz do Amaral discute a questão do "elemento servil", e repete o argumento senhorial de que não foi a abolição, mas a forma com a qual ela foi feita, que gerou "problemas" ao Brasil:

\footnotetext{
37 Ibid., p. 94.

38 Idem. p. 98

39 Idem, p. 199.

40 Sobre o racialismo propagado pelos intelectuais baiano da Primeira República ver ARAÚJO, Mariele s. A medida das raças na mistura imperfeita: Discursos Racialistas em Pedro Calmon - 1922/33. (Dissertação de Mestrado em História), UFBA, Salvador, 2006.
} 
Os proprietários de escravos tinham um espantoso prejuízo e, aliás, não Ihes cabia culpa da execrável instituição, até ai reconhecida e taxada pelo governo, pelo que não deviam esperar que este assim procedesse com eles. [...] A abolição devia ter sido feita com a respectiva indenização. Os antigos senhores se curvaram ao prejuízo e à ruína [...]. ${ }^{41}$

Já Pedro Calmon em seu livro História da Bahia: um resumo didático, cujo fim era ensinar as novas gerações baianas sobre o passado, contado na visão da elite relembra que: "A abolição total foi feita em breves dias, de afogadilho, quase de surpresa, em 1888, quando, novamente, regia o Império a Princesa Isabel (...). Aprovado [o projeto] por aclamação, que ela sancionou em 13 de maio (por isso, Ihe ficou o cognome de "Redentora"), por entre festas estranhas na Corte". ${ }^{42}$

Para Amaral e Calmon, assim como para boa parte das elites baianas, a abolição era um processo no qual os grandes prejudicados foram os proprietários rurais. As lamentações de senhores e senhoras de engenho ressoaram anos depois nos escritos desses autores e esses traziam consigo uma idéia de que o fim do elemento servil deveria ser atribuído a um ato político da princesa, que se deu de maneira isolada, sem a participação dos principais prejudicados, na realidade, pela escravidão. Esse discurso negava aos libertos e seus descendentes a condição de autores de sua própria liberdade. A partir dessas mesmas premissas afirmou-se a incapacidade dos negros de assumirem a condição de cidadãos no pós-abolição. A "verdade histórica" é que não se "cabia a culpa" da escravidão aos senhores e que os escravos dependeram da "ação da Princesa Redentora" para alcançar a sua liberdade.

Apenas sete anos depois da publicação de Braz do Amaral e três anos da de Pedro Calmon, entrou em circulação o romance de Marques que contrariava a lógica dominante. Ele constrói uma narrativa que coloca o negro como agente de sua libertação, demonstra a inteligência dos mesmos em perceber que as leis abolicionistas eram prenuncio de liberdade, expõe os conflitos provocados pelos ataques quilombolas, ante a inércia senhorial, por fim, coloca ex-escravos e ex-senhores em pé de igualdade quando promove o casamento do filho de um ex-escravo com a filha de uma ex-senhora.

${ }^{41}$ BRAZ DO AMARAL. História da Bahia: do Império à Republica. Bahia, Imp. Of. do Estado, 1923. p. 316.

42 CALMON, Pedro. História da Bahia: resumo didático. Rio de Janeiro: Editores Bastos Leite, 1927. 186. 
Ao analisar a temática da abolição e da cidadania dos "homens de cor" no momento posterior deve-se ter em mente a desconstrução das tradicionais oposições traçadas entre escravidão e liberdade. "Escravidão" e "liberdade" não são termos antitéticos, e o terreno que separa um conjunto complexo de experiências que se abriga em cada um deles merece nossa atenção. [...] 0 território da liberdade é pantanoso e muitos dos sinais que sacralizaram a subordinação e a sujeição tornaram-se parte de um ambíguo terreno no qual ex-escravos e "livres se cor" tornaram-se cidadãos em estado contingente: quase cidadãos. ${ }^{43}$

É num complexo território de práticas sociais, que envolvem relações entre pessoas marcadas por identidades sociais variadas, que inusitadas combinações dos significados de liberdade, cor e cidadania ganham e produzem novos significados. Nos primeiros anos republicanos, o trabalho de reorganização e re-significação dessas representações culturais interpelará o re-estabelecimento das relações de poder e isso repercutirá na Obra de Xavier Marques. Ele conferirá o ponto de vista de alguém que viveu as experiências históricas do processo da abolição e as primeiras experiências do Brasil republicano, tendo sido abolicionista e republicano radical.

A comparação da obra de Marques, com outra de Anna Ribeiro, onde a temática do fim da escravidão vem à tona, fica clara a disputa simbólica travada no campo da ficção. Percebe-se, por exemplo, que enquanto em Letícia, de Anna Ribeiro, a doença do Sr. Travassos é provocada pelo "golpe" da abolição, em As voltas da estrada, de Xavier Marques, o Visconde de Athaípe cai apoplético ante a invasão dos negros quilombolas em seu engenho, morrendo pouco tempo depois. Sobre esta questão Xavier Marques é mais explicito quando afirma que "Morto o visconde de Athaípe, abatida a coluna social de Amparo, a previsão dos males decorrentes desse novo desastre prostrou as outras vitimas da Nêmeses negra que as perseguia como uma obsessão. ${ }^{44}$ Ainda no enterro, os senhores temiam serem acometidos por um ataque dos quilombolas ao longo da estrada. "Mais mortos que vivos, os

43 CUNHA, Olívia Maria Gomes da Cunha e, GOMES, Flávio dos Santos (Orgs). Quase-cidadão: histórias e antropologias da pós-emancipação no Brasil. FGV, São Paulo: 2007. pp. 10-12

44 MARQUES, Op. Cit, pp. 186-187. 
senhores de engenho encomendaram-se a Deus". 45 Em Letícia, Anna Ribeiro se restringe apenas a descrever a míngua do velho Travassos, através de uma carta que Letícia manda para uma amiga: "o médico que o assiste, declaroume que se aproximava rapidamente o desenlace fatal. Ah! Minha amiga! Que fazer em tão terrível emergência! A tua presença me daria coragem para não sucumbir ao golpe. ${ }^{46}$

Enquanto em Letícia os senhores e sua lavoura são "pegos" de surpresa pela Lei de 13 de maio, em As voltas da Estrada o processo abolicionista resulta da implantação das leis abolicionistas e da pressão exercida pelos escravos, que ao perceber que a "abolição estaria por vir" promoveram levantes e formaram um quilombo. Nos levantes vários incêndios a lavouras, assassinatos e mortes marcariam o conflito que teve na Lei do Ventre Livre, em 1871, o seu ponto de partida. Em Letícia, a Lei de 13 de maio é apresentada como um marco para a sociedade baiana, uma vez que redireciona as relações entre os dominantes e os dominados. Esse evento entra na memória social daqueles que ali as viveram como o símbolo das transformações de uma sociedade secular. Em As voltas da estrada ele praticamente não aparece, pois a abolição seria fruto de um processo que, ao contrário do que é destacado em Letícia, não é a Princesa Isabel, mas os abolicionistas, os escravos e a imprensa são aqueles que conseguiram à força o fim da instituição servil. Nazário, o líder do Quilombo, representaria em última instância a revolta dos cativos pela vida de violência e de exploração vividas pelos negros nos tempos da escravidão. Note-se, porém, um detalhe importante: um mestiço - e não um negro ou um branco - é responsável pelas revoltas que ajudaram a pressionar o governo para decretar a abolição. Isso nos coloca nos leva um pouco mais além na proposta de análise: as disputas simbólicas pelas memórias da abolição, não era o único tema do romance. Tratava-se também de colocar as questões raciais na ordem do dia. No seio desta discussão estava a formação de uma nova raça, aquela que ajudaria a construir uma nação genuinamente brasileira.

Se atentarmos, por exemplo, para o título do livro As voltas da estrada e olharmos para o sentido que ele ganha no contexto da obra, podemos perceber

\footnotetext{
45 Idem, p. 195.

${ }^{46}$ BITTENCOURT. Letícia. Op. cit., pp. 105-106.
} 
que o autor talvez estivesse discutindo sobre a emergência de uma raça "brasileira", mestiça, inscrita no personagem Nazário. O herói da trama, nos tempos do Império, foi dominado, mas na nova República, passou a ser o dominador. Essa discussão talvez seja uma das mais férteis a serem feitas no momento da construção da tese, pois envolve não a dinâmica interna do texto, mas uma complexa tessitura que transitou entre a ficção e a sociedade baiana e brasileira no decorrer da Primeira República. Esta "verdade do simbólico" mostrada pelo autor é impensável na obra de Anna Ribeiro, pois ela parte de outras perspectivas e concepções, a das tradicionais elites agrárias. Pela distinção, a produção de Xavier Marques pode oferecer possibilidades de análise sobre as memórias da escravidão e da abolição pensadas como condutoras das idéias de raça e cidadania negra não só na Primeira República como na atualidade.

\section{Referências Bibliográficas:}

1. ARAÚJO, Mariele s. A medida das raças na mistura imperfeita: Discursos Racialistas em Pedro Calmon - 1922/33. (Dissertação de Mestrado em História), UFBA, Salvador, 2006.

2. ALBUQUERQUE, Wlamyra R. de. O jogo da dissimulação: abolição e cidadania negra. São Paulo: Companhia das Letras, 2009.

3. CALMON, Pedro. Discurso do senhor Pedro Calmon. Revista da Academia Brasileira de Letras. [S/N], São Paulo, 1942.

4. CÂNDIDO, Antonio. ROSENFELD, Anatol. PRADO, Décio de Almeida. GOMES, Paulo Emilio Salles. Personagem de ficção. Coleção Debates, 7aㅡ ed. São Paulo: 1968.

5. CHALHOUB. Sidney e PEREIRA, Leonardo. (org.), História Contada. Rio de Janeiro, Nova Fronteira, 1998.

6. CUNHA, Silvio Humberto dos Passos. Um Retrato Fiel da Bahia: sociedade-racismo-economia na transição para o trabalho livre no Recôncavo açucareiro, 1871-1902. UNICAMP, (Tese de Doutorado em Economia), 2004.

7. CUNHA, Olívia Maria Gomes da Cunha e, GOMES, Flávio dos Santos (Orgs). Quase-cidadão: histórias e antropologias da pós-emancipação no Brasil. FGV, São Paulo: 2007.

8. FRAGA FILHO, Walter. Encruzilhadas da liberdade: histórias de escravos e libertos na Bahia (1879-1910). Campinas, SP: Editora da Unicamp, 2006.

9. FONTES, Nancy Rita Vieira. A bela esquecida das letras baianas: a obra de Anna Ribeiro. (Mestrado em Letras/UFBA), Salvador-Ba, 1995.

10. JESUS. Liliane Vasconcelos de. Xavier Marques: interprete da Bahia na virada do século. In: Encontro Regional da ABRALIC: Literaturas, Artes, Saberes, São Paulo, 2007. 
11. MATTOSO, Kátia M. de Queirós. A opulência na província da Bahia. In: ALENCASTRO, Luiz Felipe de. História Privada do Brasil. São Paulo: Companhia das Letras, 1997. Vol. 02).

12. MATA, lacy Maia. Libertos do 13 de maio" e ex-senhores na Bahia: conflitos no pós-abolição. Afro-Ásia. no 35. pp. 163-198. Salvador, 2007.

13. OLIVEIRA, Marcelo Souza. Fios literários na teia da História: paternalismo, escravidão e pós-abolição num romance de Anna Ribeiro. In: Revista Em Tempo de Histórias, Publicação do PPGHIS/UnB, n.11, Brasília, 2007. http://www.unb.br/ih/novo portal/portal his/revista/index.html, acesso em 08

14. de junho de 2009.

Uma senhora de engenho no mundo das letras: o 15. declínio senhorial na obra de Anna Ribeiro. EDUNEB, Salvador, 2009. Memórias de uma senhora de engenho lembranças e esquecimento nos Longos Serões do Campo de Anna Ribeiro. In: Patrimônio e Memória. São Paulo, 2008.

16. PESAVENTO, Sandra Jatahy. Em busca de uma outra história: imaginando o imaginado. Revista Brasileira de História, Vol. 15, ㄲo. 29, ANPUH; Contexto, São Paulo: 1995.

17. SANTOS, Paulo Silva. Âncoras de Tradição: luta política, intelectuais e construção do discurso histórico na Bahia, Salvador: EDUFBA, 2000. 